\section{Zero-Background Plasmid Vector for BAC Library Construction}

BioTechniques 26:228-232 (February 1999)

Bacterial artificial chromosome (BAC) vectors based on the Escherichia coli $\mathrm{F}$ episome have been developed to construct libraries with large DNA inserts in E. coli $(2,4-6)$. Although BAC vectors are still being refined and improved, they have solved many of the problems associated with yeast artificial chromosome (YAC) vectors. For example, the low copy number of the $\mathrm{F}$ factor, the use of recombination and restriction methylation mutants all reduce the potential for recombination and instability seen in YACs. However, we encountered a number of limitations associated with the most widely used $\mathrm{BAC}$ vector, $\mathrm{pBe}$ loBAC11 (8). First, even under optimal ligation conditions using dephosphorylated plasmid vector DNA, we regularly found a high proportion of nonrecombinant colonies (up to $50 \%$ of the colonies on isopropyl- $\beta$-D-thiogalactopyranoside [IPTG] and 5-bromo-4-chloro-3-indolyl- $\beta$-D-galactopyranoside [X-gal] plates were blue). Second, precise optimization of the vector-to-insert ratio used for ligation was required. Equal molarity of vector and insert led to a poor transformation efficiency. In contrast, excess vector (10-fold molarity of vector-to-insert ratio) led to a high proportion of colonies without insert. Thus, efficient library construction required preparation of high-quality dephosphorylated vector and several trial experiments to identify the optimal concentration of vector DNA.

To facilitate efficient library construction, an alternative vector, $\mathrm{pBAC} /$ SACB1, was constructed. To reduce the need for precise optimization of ligation conditions, the pBAC/SACB1 vector was designed for positive selection of $E$. coli cells carrying recombinant plasmids. The vector was based on $\mathrm{pBe}$ loBAC11 but carried the $\operatorname{SacB}$ gene from Bacillus amyloliquefaciens (7) instead of LacZ. SacB encodes the enzyme, levansucrase, that catalyzes the hydrolysis of sucrose to generate the lethal product levan. Thus, expression of $S a c B$ kills cells that are grown on sucrose (7). In pBAC/SACB1, we placed the $S a c B$ gene under the control of the IPTG inducible promoter ( $L a c$ operator) (Figure 1A). In a previously described PAC vector, a pUC19 replicon was inserted between the promoter and $S a c B$ open reading frame (ORF) (3). This approach was used to purify bulk quantities of vector DNA and to inactivate the expression of $\mathrm{SacB}$ when selection was not desired (3). In pBAC/ $\mathrm{SACB} 1$, the expression of the $\mathrm{SacB}$ gene to a toxic level is completely dependent on the presence of IPTG and sucrose in the growth media. A unique Bam HI cloning site was introduced between the promoter and the $S a c B$ ORF (Figure 1A). Thus, an insert in the BamHI site separates the promoter from $S a c B$ and permits growth on L-agar medium containing sucrose and IPTG. Using this system, complete dephosphorylation of the vector and the ratio of insert to vector in the ligation were found to be less critical for successful ligations than with pBeloBAC11.

Using pBAC/SACB1, we constructed a potato BAC library of 15000 clones with an average insert size of $100 \mathrm{~kb}$. High-molecular-weight DNA was prepared in agarose plugs $(9 \mu \mathrm{g}$ per plug) from potato protoplasts. The agarose plugs were dialyzed $3 \times$ for 30 min against TE $(10 \mathrm{mM}$ Tris- $\mathrm{HCl}, 1$ $\mathrm{mM}$ EDTA, $\mathrm{pH} 8.0$ ) first at $25^{\circ} \mathrm{C}$ and then $2 \times$ at $4^{\circ} \mathrm{C}$. The plugs were then equilibrated $2 \times$ in Bam HI buffer (100 $\mu \mathrm{g} / \mathrm{mL}$ bovine serum albumin [BSA], $10 \mathrm{mM}$ Tris- $\mathrm{HCl}, 10 \mathrm{mM} \mathrm{MgCl} 2,150$ $\mathrm{mM} \mathrm{NaCl}, 1 \mathrm{mM}$ dithiothreitol [DTT], $\mathrm{pH}$ 7.9) on ice for $2 \mathrm{~h}$. Half of each plug was transferred to a microcentrifuge tube containing $360 \mu \mathrm{L}$ of BamHI buffer and 10-15 U of BamHI restriction enzyme. The enzyme was allowed to diffuse into the plug at $4^{\circ} \mathrm{C}$ for $1 \mathrm{~h}$, and the digestion was carried out at $37^{\circ} \mathrm{C}$ for $30 \mathrm{~min}$. Digestion was stopped by the addition of $36 \mu \mathrm{L}$ of 0.5 $\mathrm{M}$ EDTA, $\mathrm{pH}$ 8.0. The plugs were washed in $0.5 \times$ TAE $(20 \mathrm{mM}$ Trisacetate, $0.5 \mathrm{mM}$ EDTA, $\mathrm{pH} 8.0$ ) and loaded onto a $1 \%$ SeaPlaque ${ }^{\circledR}$ GTG $^{\circledR}$ Low Melting Point Agarose Gel (FMC BioProducts, Rockland, ME, USA), and the DNA fragments were fractionated by pulse-field gel electrophoresis (PFGE) using the CHEF-DR ${ }^{\circledR}$ III Sys- tem (Bio-Rad, Hercules, CA, USA) in $0.5 \times$ TAE for $2.5 \mathrm{~h}$ using 2 -s switch time, a reorientation angle of $90^{\circ}$ and fields of $9 \mathrm{~V} / \mathrm{cm}$. Agarose slices containing partially digested DNA from the $100-\mathrm{kb}$ compression zone were dialyzed against $30 \mathrm{~mL} \mathrm{TE}$ for $2 \mathrm{~h}$ at $4^{\circ} \mathrm{C}$, melted at $65^{\circ} \mathrm{C}$ for $10 \mathrm{~min}$ and digested with GELase ${ }^{\mathrm{TM}}$ (Epicentre Technologies, Madison, WI, USA) for $1 \mathrm{~h}$ at $45^{\circ} \mathrm{C}$ ( $1 \mathrm{U}$ of GELase was used per 100 $\mathrm{mg}$ of $1 \%$ agarose gel). Using this procedure with a pulse-field gel fractionation that is shorter than described previously allows digestion of potato DNA, gel fractionation and ligation to be carried out all on the same day. This rapid processing time reduces the risk of DNA degradation.

The pBAC/SACB1 vector DNA was extracted by the alkaline lysis method and purified by cesium chloride/ethidium bromide equilibrium centrifugation at $200000 \times g$ (4). The pBAC/SACB1 vector DNA was digested with BamHI and dephosphorylated with shrimp alkaline phosphatase according to the manufacturer's instructions (Amersham Pharmacia Biotech, Piscataway,

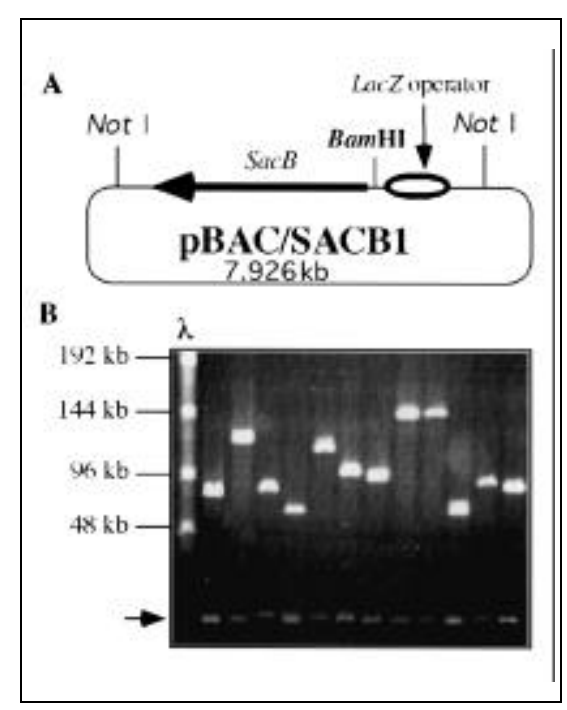

Figure 1. Map of pBAC/SACB1 and results from restriction analysis of plasmid DNA. (A) Schematic diagram of pBAC/SACB1 plasmid vector. (B) PFGE analysis of DNA isolated from 12 colonies picked at random from the potato BAC library. Plasmid DNA was digested with NotI and separated by PFGE overnight in $0.5 \times$ TBE (8) at $150 \mathrm{~V}$ using pulse time ramping from 5-15 s. The insert size of the BAC clones was estimated by comparison to lambda concatemers $(\lambda)$. The arrow indicates the linearized pBAC/ SACB1 vector DNA. 
NJ, USA). The ligation was performed at $16^{\circ} \mathrm{C}$ for $24 \mathrm{~h}$ in ligation buffer $(50$ $\mathrm{mM}$ Tris-HCl, $\mathrm{pH} 7.5,10 \mathrm{mM} \mathrm{MgCl}{ }_{2}$, $10 \mathrm{mM}$ DTT, $1 \mathrm{mM}$ ATP, $25 \mu \mathrm{g} / \mathrm{mL}$ BSA). A ligation volume of $50 \mu \mathrm{L}$ included (i) approximately 25-50 ng of the size-selected potato DNA, (ii) 25-50 ng of BamHI-digested vector and (iii) 400-800 U of T4 DNA Ligase (New England Biolabs, Beverly, MA, USA). The ligation products were dialyzed against $0.5 \times \mathrm{TE}$ buffer using the "drop dialysis" method (3). E. coli DH10B cells (Life Technologies, Gaithersburg, MD, USA) were transformed by electroporation as described by Frijters et al. (1). Cells were plated on L-agar containing chloramphenicol $(12.5 \mu \mathrm{g} / \mathrm{mL})$, sucrose $(146 \mathrm{mM})$ and IPTG $(0.12 \mathrm{mg} / \mathrm{mL})$ and incubated at $37^{\circ} \mathrm{C}$ for $24 \mathrm{~h}$. Figure $1 \mathrm{~B}$ shows an analysis of 12 random BAC colonies. All 12 clones contained the vector DNA and an insert. This high efficien- cy of library construction reduces the number of colonies that have to be processed and allows the use of an automated colony picker for transfer of BAC clones into ordered arrays. However, in our experience these devices have proven unreliable when it is necessary to distinguish between blue and white colonies.

To check insert stability in the pBAC/SACB1 vector, 4 BAC clones each carrying $100-\mathrm{kb}$ inserts were cultured overnight in $50 \mathrm{~mL}$ of L-broth containing $12.5 \mu \mathrm{g} / \mathrm{mL}$ of chloramphenicol. Each clone was subcultured four successive times. In each step, an overnight culture was diluted $10^{6}$-fold in $50 \mathrm{~mL} \mathrm{~L}$-broth and regrown overnight. Each passage was considered to represent about 20 generations. BAC DNA was prepared from the original culture (defined 0 generation) and from the final culture representing the 80 generations. The DNA was analyzed by digestion with HindIII restriction enzyme and fractionated on a $1 \%$ agarose gel. No rearrangements of BAC DNA were observed (data not shown).

Thus, the use of $S a c B$ under the control of an inducible promoter in $\mathrm{pBAC} / \mathrm{SACB} 1$ enhances the ease of use of $\mathrm{BAC}$ vectors for construction of large DNA libraries.

\section{REFERENCES}

1.Frijters, A.C.J., Z. Zhang, M. vanDamme, G.L. Wang, P.C. Ronald and R.W. Michelmore. 1997. Construction of a bacterial artificial chromosome library containing large EcoRI and HindIII genomic fragments of lettuce. Theo. Appl. Gen. 94:390-399.

2.Hosoda, F., S. Nishimura, H. Uchida and M. Ohki. 1990. An F-factor based cloning system for large DNA fragments. Nucleic Acids Res. 18:3863-3869.

3.Ioannou, P.A., C.T. Amemiya, J. Garnes, P.M. Kroisel, H. Shizuya, C. Chen, M.A. Batzer and P.L. de Jong. 1994. A new bacteriophage P1-derived vector for propagation of 
large human DNA fragments. Nature Genet. 6:84-89.

4.Leonardo, E. and J. Sedivy. 1990. A new vector for cloning large eukaryotic DNA segments in Escherichia coli. Bio/Technology 8:841-845

5.O'Connor, M., M. Peifer and W. Bender. 1989. Construction of large DNA segments in Escherichia coli. Science 244:1307-1312.

6.Shizuya, H., B. Birren, U.J. Kim, V. Mancino, T. Slepak, Y. Tachiiri and M. Simon. 1992. Cloning and stable maintenance of 300 kilobase-pair fragments of human DNA in Escherichia coli using an F-factor-based vector. Proc. Natl. Acad. Sci. USA 89:8794-8797.

7.Tang, L.B., R. Lenstra, T.V. Borchert and V. Nagarajan. 1990. Isolation and characterization of levansucrase-encoding gene from Bacillus amyloliquefaciens. Gene 96:89-93.

8. Woo, S., J. Jiang, B. Gill, A. Paterson and R. Wing. 1994. Construction and characterization of a bacterial artificial chromosome library of Sorghum bicolor. Nucleic Acids Res. 22:4922-4931

We are grateful to the Gatsby charitable foundation for continuing support, and to $S$. Angell, T. Lahaye and D. Baulcombe for valuable discussions. Address correspondence to Dr. Abdelhafid Bendahmane, The Sainsbury Laboratory, John Innes Centre, Colney, Norwich, NR4 7UH, England, UK. Internet: bendahm@bbsrc.ac.uk

Received 13 July 1998; accepted 19 October 1998.

\section{Abdelhafid Bendahmane John Innes Centre Colney, Norwich, England, UK}

\section{Complex Methylation Patterns Analyzed by Single-Strand Confor- mation Polymorphism}

\section{BioTechniques 26:232-234 (February 1999)}

Bisulfite genomic sequencing is one of the most frequently used methods to study the methylation status of cytosines in $\mathrm{CpG}$ islands (3). Following bisulfite treatment of DNA, the unmethylated cytosines are converted to uracil, whereas the methylated cytosines remain unchanged. DNA frag- ments containing modified and/or unmodified cytosines are amplified by polymerase chain reaction (PCR), cloned and sequenced, providing a methylation map of the genomic regions of interest. Direct sequencing of PCR products can also be used to determine the methylation status of cytosines and the degree of methylation in a given $\mathrm{CpG}$ (6).

The study of the methylation status of tumor-suppressor genes has become important in cancer research. In tumor cells, the two (or more) alleles of a gene localized within a $\mathrm{CpG}$ island often have different methylation states and patterns $(4,7)$. Moreover, when primary (uncultured) tumors are studied, tumor cells are contaminated with non-tumor cells. For these reasons, many clones must be sequenced to obtain a representative picture of the different methylation patterns of a given gene within a neoplasm. To facilitate this time-consuming procedure, we developed a simple method based on nonradioactive single-strand conformation polymorphism (SSCP) to screen individual clones before sequencing.

Genomic DNA from colon carcinoma cell lines (HT29, HCT116, Co115, AltI, Isreco1 and EE39C) was chemically modified with sodium bisulfite as described by Clark et al. (2). A 255-bp fragment of the p16-beta gene (5) (exon 1) containing $27 \mathrm{CG}$ dinucleotides was amplified by PCR using the following primers complementary to the deaminated DNA strand: primer 1, 5'-GGGTTTTAGTTTGTAGTT-3' and primer $2,5^{\prime}$-CCTCAATAACATCAACAC-3'. After a hot start of $8 \mathrm{~min}$ at $98^{\circ} \mathrm{C}$ and the addition of $\mathrm{Taq}$ DNA Polymerase (Qiagen $\mathrm{GmbH}$, Hilden, Germany) at $73^{\circ} \mathrm{C}, 30$ cycles of $45 \mathrm{~s}$ at $94^{\circ} \mathrm{C}, 60 \mathrm{~s}$ at $48^{\circ} \mathrm{C}$ and $60 \mathrm{~s}$ at $73^{\circ} \mathrm{C}$ were performed, followed by a final 15 min extension step at $73^{\circ} \mathrm{C}$. Amplified DNA was cloned into a pGEM ${ }^{\circledR}$-T Vector (Promega, Madison WI, USA) as recommended by the manufacturer. Ten clones from each PCR product were sequenced on an $\mathrm{ALF}^{\circledR}$ Automatic DNA Analysis System (Amersham Pharmacia Biotech, Uppsala, Sweden). Each clone was also amplified by PCR using the same primer set and similar cycle profile as described above, but without hot start. For SSCP, $1 \mu \mathrm{L}$ of PCR product was denatured in $50 \mathrm{mM} \mathrm{NaOH}$ and $1 \mathrm{mM}$ EDTA at $50^{\circ} \mathrm{C}$ for $10 \mathrm{~min}$ and then loaded on a $10 \%$ non-denaturating polyacrylamide gel (49:1 acrylamide to bisacrylamide) containing $5 \%(\mathrm{vol} / \mathrm{vol})$ glycerol, as described previously (1). After a run at $200 \mathrm{~V}$ in $0.5 \times \mathrm{TBE}(44.5$ $\mathrm{mM}$ Tris-borate, $1 \mathrm{mM}$ EDTA, $\mathrm{pH}$ 8.3) for $16 \mathrm{~h}$ at $20^{\circ} \mathrm{C}$, the gel was fixed in $10 \%$ acetic acid for $20 \mathrm{~min}$, washed twice in water and incubated in $1 \mathrm{mg} /$ $\mathrm{mL}$ silver nitrate and $0.06 \%$ formaldehyde for $30 \mathrm{~min}$ at room temperature. The gel was then washed briefly in water and developed in a solution containing 3\% sodium carbonate anhydrous, 2 $\mu \mathrm{g} / \mathrm{mL}$ sodium thiosulfate pentahydrate

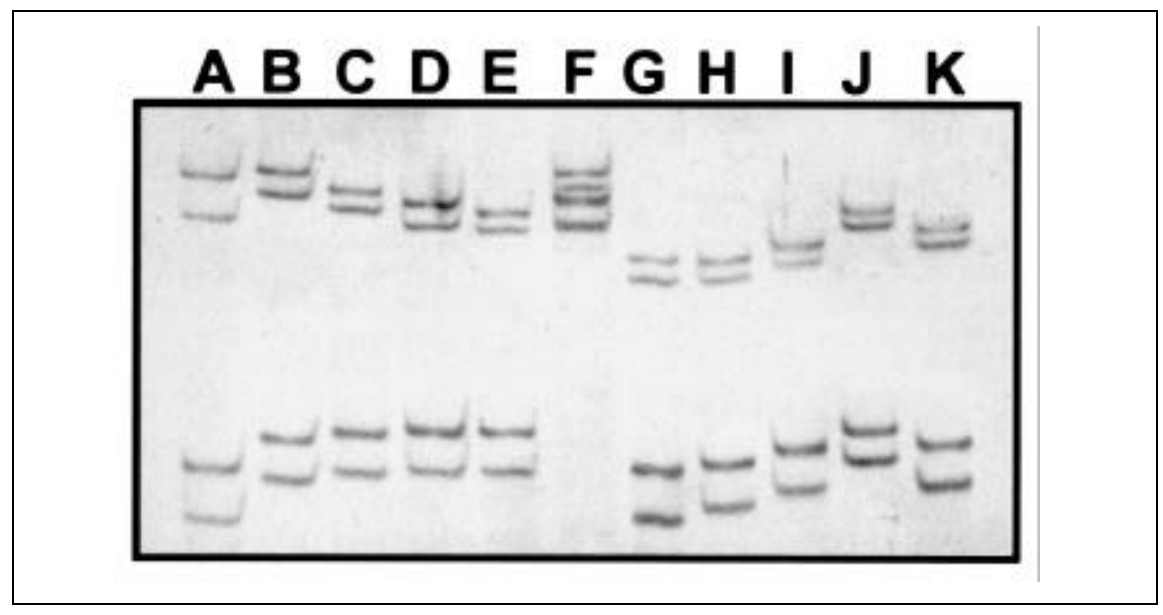

Figure 1. PCR-SSCP analysis of clones shown to be different by bisulfite genomic sequencing. Each of the 11 clones $(\mathrm{A}-\mathrm{K})$ described in Table 1 is characterized by a specific migration pattern that is easily distinguishable from the other. The 4 bands observed in each lane correspond to two 3-D structures adopted by each DNA strand at the working temperature. 